\title{
THE DYNAMICS OF INDIA-SAUDI RELATIONS: THROUGH THE GLIMPSE OF HISTORY
}

\section{RINCY MATHEW}

Phd Scholar, Department: Political Science, University of Kerala, Tamilnadu, India

\begin{abstract}
India's foreign policy was influenced by Saudi Arabia, and vice versa. With a shifting geopolitical landscape and growing economic interconnectedness, both are converging. India has a long history with Arabia. It's fascinating to learn about the history of India-Saudi relations from the outset. The search for the beginning of the relationship between the two countries dates back to 5000 BC. Going through the pages of history, it can be seen that these two cultures have come to a perfect relationship in their present form over the centuries. This article is an attempt to explore the historical background of India-Saudi relations.

KEYWORDS: Civilizational interaction, Indo - gulf trade, Pre-independence and Post-independence connections, Look east, Religious and economic dimensions.
\end{abstract}

Received: May 18, 2021; Accepted: Jun 08, 2021; Published: Jul 03, 2021; Paper Id.: IJPSLIRDEC20211

\section{INTRODUCTION}

The Indian subcontinent and West Asia have had historical connections since time. History, culture, civilization, and trade all had a role in the development of these. The centuries-old culture links between the two regions evolved into a full-fledged multi-dimensional interaction throughout the mediaeval period, often known as the age of empires. Based on new archeological evidence and genomic mapping discoveries, several researches have claimed that Indo-Gulf connections extend back to $5000 \mathrm{BC}$. Whether it was the Greco-Roman Eastern trade route, the Indus commerce with the Sumerians, the birth of Islam, or subsequent conflicts between the Ottomans and the Persians, or the Dutch and the Portuguese, Indians played a significant role. Ancient civilizational connection between India and the Gulf area was quite strong, according to studies of pottery, porcelain, tombs, coinage, and other artefacts. Dilmun, Magan, Gerrha, Socotra, and Falaika were strongly connected to Meluhha, Lothal, Dholavira, and other regions of Gujarat and the Indus valley from and around the Gulf. (Karlovsky, 1972)

India has a long history with Arabia. Many Indians used to learn medicine in Arabia. Arab merchants spread Islam to coastal towns in Kerala, Gujarat, and other parts of the interior after the emergence of Islam in the seventh century AD. As a response, many pilgrims from India visited Mecca, Madina, Bethlehem, Jerusalem, Najaf, and Karbala. Gradually, India's sea trade was taken over by the Arabs, who came to dominate the Red Sea, Gulf region, and the Indian Ocean. Many Indian Hajis stayed in the Holy Land to trade, taking local Arab wives. A large number of Indian ships arrived in Jeddah with cargoes of cotton, textiles, silk, spices, gems, and other materials from Calcutta, Surat, and Bombay. Jeddah merchants profited greatly from Indian goods, which were later trans shipped to Suez and Europe, particularly Venice and Genoa (Pasha, 1997). It is worth noting that between 1661 and 
1667, Aurangzeb received "complementary embassies" from several foreign Muslim powers, including the Sheriff of Mecca and others, in order to mitigate his harsh treatment of his faith. As the Hashimi family had ruled Mecca since the 11th century A.D., it was also customary for wealthy Indian princesses to lavishly shower gifts on the Sheriff of Mecca and the Holy Places.

When we come into the beginning of the $20^{\text {th }}$ century, On January 8, 1926, Abdul Aziz (also known as Ibn Saud) captured Mecca, Madina, and the entire Hejaz and proclaimed himself King of the Hejaz. He encountered both internal and external opposition. Furthermore, despite the European powers' quick recognition of King Saud as King of Hejaz, he had to legitimise his position in the eyes of the Islamic world, which had begun with prejudice against Wahhabism and had been scandalised by the violence with which the Puritans had suppressed the cult of saints in the conquered holy land. The people of Hejaz, particularly the followers of the Sheriff of Mecca, had to be won over and their economic grievances addressed. As a result, in order to legitimise his position as ruler of Hejaz and guardian of holy places, as well as to reassure the Muslim world, King Abdul Aziz convened an international conference. Ibn Saud issued a proclamation to the Muslim world, inviting representatives to the Hejaz to discuss the future of the Holy Places (Pasha, 2012)

The Islamic Congress convened in Mecca on June 7, 1926, during the Haj, and was attended by 60 delegates from all over the world, including the Indian Muslim community, which was led by the Ali Brothers - Khilafat Committee members. The Indian members sent to Mecca had little success because they became involved in mediation efforts to resolve the Hashamite status (Pasha, 2006). The Saudi King apparently disliked the Indian delegation's intervention because the King had declared Sheriff Hussain of Mecca a traitor for claiming the title of Caliph on March 5, 1924, which had been made vacant by Kemal Ataturk's deposition of the Ottoman Sultan. According to one writer, the Saudi King ordered the Indian delegation to leave Hejaz due to objections on a number of issues (related to Hajj, Wahhabi control of Holy Places). This was clearly an undiplomatic move. Only until the Indian delegation was removed did Ibn Saud feel comfortable. The Saudi King united Najd and Hejaz on September 23, 1932, to become the Kingdom of Saudi Arabia. Some delegates at the Islamic Conference did, in fact, object to Ibn Saud's assumption of the un-Islamic title of King. It should be noted that pilgrims for Haj from the Indian subcontinent made up one of the largest groups, and the Sheriff of Mecca and King Ibn Saud, following tradition, purchased a large number of tents from India to house the Haj Pilgrims.

Both G-20 economies and major actors in their respective areas of South Asia and West Asia, India and Saudi Arabia are growing powers. India and West Asia have a long history that precedes the British Empire's advent. For almost a millennium, the two had been linked by an overland caravan trade in silks, spices, and other commodities, as well as an Indian Ocean marine trade in calicoes (a type of cotton cloth), coffee, specie (money in the form of coins), and slaves. Beginning with the Delhi Sultanate in 1210 and continuing with the Mughal Empire in 1526, Muslim rulers of Central Asian and Turkish descent dominated a major section of North India by the thirteenth century. The Mughal military depended extensively on Central Asian irregulars and mercenaries, particularly horsemen, and during Emperor Akbar's rule (1556-1605), Persian mansabdars (ranked nobles) and jagirdars dominated the Mughal officer corps and aristocracy (holders of revenue assignments). The Persian Empire presented a danger to Mughal India, most notably when Nadir Shah (1688-1747) attacked Delhi in 1739, capturing the famed Koh-I-Noor diamond and the Peacock Throne in the process. Through shared laws, languages, scholarship, and, in principle, the spiritual guidance of the caliph, the Muslim world's ruler, Islam connected South Asia, Arabia, and the Ottoman Empire. Since most people identify the caliphate with the Ottoman sultan, it also was held by Mughal kings following Akbar. In addition, the annual hajj, or Muslim pilgrimage to 
Mecca in modern-day Saudi Arabia, provided for direct and continuous communication between western India and the Arabian Peninsula.

\section{Indo Saudi Relations in post-independence}

A review of Indian foreign policy in West Asia from 1947 to 1986 said that Indian foreign policy in the region had become too ideological and had paid no attention to the expediency by focusing on India's subdued ties with Saudi Arabia (Mudiam, 1994). India has worked hard to preserve good connections with Saudi Arabia, a significant regional power and commercial partner in West Asia, since its independence in 1947. Both nations decided to establish their relationship on the Five Principles of Peaceful Coexistence during King Saud of Saudi Arabia's significant visit to India in November 1955. The relationship between India and Saudi Arabia had not been especially friendly. Both parties were apprehensive about improving their connections. India's non-alignment strategy after independence brought it closer to Egypt and other secular states in the region. Simultaneously, Pakistani propaganda against India in Muslim countries determined Indo-Saudi relations to a large extent, and India found itself estranged from Saudi Arabia. However, there was no direct rivalry between India and Saudi Arabia (Naaz, 2005). Relations between India and Saudi Arabia began on a positive note.

Saudi Arabia was indeed a participant and signatory to the final communiqué of the inaugural Afro-Asian Conference, held in Bandung, Indonesia, in April 1955 (Mudiam,1994). The two nations' first high-level political engagement occurred in December 1955, when King Saud paid a short visit to New Delhi. The joint statement released at the conclusion of the visit revealed some political agreement between King Saud and Prime Minister Jawaharlal Nehru. Both leaders emphasised the need for cooperation in the words "a peaceful and non-militant approach to the issues that have divided the world." Saudi Arabia was even pleased with the Indian government's policy toward Muslim brothers and sisters. King Saud publicly expressed gratitude to Prime Minister Jawaharlal Nehru and his government for their Muslimfriendly policies. "I'd like to say... That Indian Muslims' faith is in good hands" (Ziring, 1990). This demonstrates that during the early years of the Indian republic, Saudi Arabia was not influenced by Pakistan. In September 1956, Jawaharlal Nehru returned to Riyadh It's worth remembering that Nehru was greeted with the slogan when he arrived in Riyadh. "Marhaba-Rasool Al-Salam," (welcome, messenger of peace) which caused a lot of unnecessary controversy, whether intentional or not. Envy and animosity existed throughout Pakistan. The Saudi Embassy in Pakistan released a statement clarifying that the phrase meant "Welcome Messenger of Peace," not "Welcome Prophet of Peace," as the Pakistanis mistook it to mean. After then, there was a long hiatus, with no head of state or government visiting for nearly 26 years. The two most prevalent grounds for Indo-Saudi estrangement were tight Indo-Egyptian connections and secondly close Saudi-Pakistan contacts. India's ties with Saudi Arabia were strained by Nehru's backing for Nasser as the only and indisputable leader of rising Arab nationalism. Saudi Arabia saw Nasser's extreme Arabism as a danger, causing him to "turn to Pan-Islamism as a counter-strategy, which India attempted to oppose and weaken by backing Nasser." Saudis were dubious and disgruntled of Nehru's support for Nasser. As a result, Indo-Egyptian relations, along with Pakistan's goal for Islamic unity, operated against India and significantly skewed Indo-Saudi relations.

\section{An Interlude by Pakistan}

According to an analyst, Pakistanis' close ties with Saudi Arabia have been recognized. "Saudi Arabia is the Islamic world's heartland, and the ruler of Saudi Arabia is the custodian of the 'Haramaine- Sharifain.' (Harmain Shareefain (meaning Makkah \& Madina) is a dual plural noun of Haram Shareef (meaning Makkah or Madina). As a 
result, there is no need to elaborate on the Pakistani people's feelings toward Saudi Arabia" (Hussain, 1989). In foreign policy, Pakistan stressed its Islamic identity and made special initiatives to promote Muslim unity. "Our ties with Muslim nations should not only be cordial, but fraternal," Liaquat Ali Khan, Pakistan's first Prime Minister, said, "and they should be strengthened on a daily basis since Pakistan's mission (can) attain success only if other Muslim countries join it." The statement is a clear example of how religion would be used for political purposes in the formulation of Pakistan's foreign policy in the future. Pakistan's administration began to promote the cause of Muslims all over the world after the country was created., and in the early 1950s, it moved aggressively to promote cooperation among Muslim states. The majority of Muslim states, however, reacted negatively to Pakistan's efforts because "the Pakistani leaders, in their enthusiasm for projecting Islam in foreign policy, did not take into account the political realities that persisted in the Muslim world in the 1950s." In western Asia, Muslims were not a minority, and they did not see a non-Muslim majority as a danger to their social, political, or economic interests, nor did Islam play a key part in nationalist conflicts. The majority of Arab governments faced a plethora of problems as a result of Western colonisation. The Hindu-Muslim clash, on the other hand, influenced Pakistani leaders' perspectives."

Pakistan's decision to join the SEATO (South East Asia Treaty Organization) and the Baghdad Pact CENTO (Central Treaty Organization) in the 1950s damaged Pakistan's ties with a number of Muslim governments. Pakistan's membership in the Baghdad Pact has been described as a "stab in the heart of Arab and Muslim governments" by Saudi Arabia. Pakistan's relations with Arab countries have deteriorated dramatically. As a result, Pakistan reconsidered its policy of total identification with the West and began cultivating relations with other powers such as the USSR, China, and Muslim states. As a result, Saudi Arabia established close ties with Pakistan. The fact that the name of the Pakistani city of Lyallpur has been changed to Faisalabad attests to the close relationship between Saudi Arabia and Pakistan. Saudi Arabia also funded the establishment of the International Islamic University in Islamabad (Ralph Braibanti, 1996).

During the 1965 Indo-Pakistan war, Saudi Arabia openly supported Pakistan. According to a statement issued by the Saudi Arabian Embassy in Karachi, "India was committing aggression against Pakistan as well as the Kashmiri people." In addition, "Amir Mishal, brother of Saudi King Faisal and Governor of Mecca, and other leading families of Jeddah volunteered to fight for Pakistan" (Rizvi, 1993). Mr. Omar Askkaf, the Saudi Arabian delegation's chairman, restated his country's support for Pakistan's demand for a referendum in Kashmir at the United Nations General Assembly on October 15, 1965." He went on to say, "The people of Kashmir, or any other people for that matter, cannot be silenced for long once they become aware of their right to determine their own future." On September 21, 1965, King Faisal declared that "India was the aggressor against Pakistan, and it was the duty of every peace-loving country to support Pakistan" (Rai, 1981). Similarly, during the 1971 Indo-Pak war, Saudi Arabia blamed India for the conflict and openly supported Pakistan. The Saudi Government declared during a cabinet meeting on December 6, 1971, that the nations of the world should denounce India for conducting open hostilities against Pakistan. King Faisal proposed a special Muslim conference to provide moral and material support to Pakistan.

Saudi Arabia's global importance grew following the oil boom of the early 1970s. It was bolstered further by the rise of Islamic resurgence. At the same time, it became necessary for India to try to balance Pakistan's exploitation of its Islamic status. Apart from President Fakhruddin Ali Ahmad's 1975 visit to Saudi Arabia to attend King Faisal's funeral. This could be attributed to the subcontinent's new political climate as a result of the Simla agreement and the release of Pakistan's POWS (Prisoners of war). Saudi Arabia's Minister of Petroleum and Mineral Resources, Sheikh Ahmad Zaki 
Yamani, visited India in February 1975 (Affairs, 1975). During his visit, he agreed that the two countries' cooperation had enormous potential. He stated that "we will seek India's technical cooperation in important fields of economic activity." The two leaders also discussed the possibility of forming joint ventures in the pharmaceutical, fertilizer, and petrochemical industries. This visit was significant because it rekindled a dormant relationship.

During the Bangladesh crisis of 1971, the Saudi attitude was similar to that of many other nations, which maintained that what was happening in East Pakistan as Pakistan's domestic matter and that no other country had the authority to act. The war between East and West Pakistan was "most likely for economic as well as political motives," Saudi delegates at the UN Security Council stated on December 16, 1971. "Without international intervention, only India and Pakistan can handle the problem," he added. The Bangladesh event, on the other hand, had a significant influence on Indo-Saudi ties since it proved to be a barrier to developing political understanding between the two nations at a time when the environment in both areas was favorable for such an effort. Despite its reputation as a politically conservative state, Saudi Arabia's regional strategy had a number of features that were aligned with India's own thinking and inclinations in the area even in the 1960s. Around this time, the Saudis also recognised the limitations of their relationship with Pakistan, and despite a shared goal to develop "Islamic cooperation in industrial sectors," little progress was being made in that direction due to Pakistan's low petroleum demands. As a result, the Saudis saw the importance and value of developing India, both economically and politically. After the Al-Aqsa mosque was set on fire in 1969 (under Israeli rule), King Faisal called an Islamic meeting to examine the situation. King Hassan of Morocco, on the other hand, foiled Faisal's plans to host the summit at Mecca and instead held it in Rabat, his own city. Faisal was uncomfortable with his role as "joint convener" of the Summit. Because the topic at Rabat was restricted to the burning of the Al-Aqsa mosque, and any fresh suggestion on Palestine would be rejected by Iran and Turkey, King Faisal developed the notion of inviting India to establish his power and centrality at the summit. Faisal benefited greatly from India's desire to attend the summit in order to block any attempts by Pakistan to bring up bilateral concerns with India. President Yahya Khan of Pakistan, on the other hand, won the day by threatening to skip the summit if India showed up, and King Faisal's approach failed catastrophically.

The Arab catastrophe of the 1967 war further lowered Egypt's reputation in Arab eyes, and Nasser's popularity is at an all bottom. Nasser, therefore, intended to form a wide Arab national front by gaining the support of previously reviled Arab governments based on ideological reasons. Egypt's withdrawal of soldiers from North Yemen put an end to the most serious cause of conflict between Egypt and Saudi Arabia, and also indicated Nasser's new Arab unity plan. With Nasser's death in 1970, an era in Arab politics came to an end, as did India's "special connection" with Egypt, removing the shadow that had hovered over Indo-Saudi ties. Saudi Arabia and Pakistan had a close partnership in the mid-1960s, which is evident in Saudi sentiments regarding the 1965 and 1971 Indo-Pak conflicts. In both instances, Saudi Arabia took an essentially hostile posture toward India, supporting Pakistan politically, diplomatically, militarily, and economically. Between the two wars, Saudi Arabia helped to institutionalise Pan Islamism by founding the Organization of Islamic Conference (OIC) in 1971, following the Rabat Summit of 1969. The devastating loss of Egypt in the 1967 war, Saudi Arabia's strong financial clout, the August 29, 1969, burning of Al-Aqsa Mosque (Jerusalem), Nasser's death in September 1970, and other events aided Saudi leadership's steady rise in the Arab/Islamic world. The fact that the OIC's headquarters are in Jeddah is proof of this. Pakistan has taken full advantage of this ever since the OIC has been a recurring foreign policy nightmare for India, as Pakistan has consistently used the conference to highlight Kashmir problems in order to stir Islamic sentiment, with Saudi assistance. There was little opportunity for India and Saudi Arabia to negotiate a political 
agreement under these circumstances. The region's advancements in the late 1970s and early 1980s further served to deepen the perceived gap between the two countries.

\section{Indo-Saudi ties in the 1980s}

The overthrow of Iran's Shah in early 1979, the Soviet invasion of Afghanistan in December 1979, and the start of a fullfledged war between Iran and Iraq in September 1980 only served to reaffirm and irritate India's and Saudi Arabia's longheld concerns and anxieties. Saudi Arabia's domestic vulnerability, fears of Khomeini's brand of Islamic fundamentalism spreading throughout the region, and the significant Soviet military presence in Afghanistan all contributed to Saudi Arabia's acute sense of insecurity, driving her headlong into a closer and more extensive military relationship with the US and Pakistan, a development India viewed with substantial anxiety. The Saudis, on the other hand, were dissatisfied with India's relatively quiet and understated response to the Soviet invasion of Afghanistan. The Saudis were anxious because the Soviet occupation of Afghanistan and the large American buildup in the Indian Ocean had created a tense situation in the volatile Gulf region, which was crucial to Saudi security. They were also apprehensive about relying almost solely on American military protection, which they feared would be useless if Saudi Arabia faced a situation comparable to Iran's. In such a precarious situation, a segment of Saudi Arabia's hierarchy considered that cultivating a country like India, which could exert some influence over the Soviet Union, was preferable to wooing merely Pakistan. For its part, India wanted to persuade Saudi Arabia of the necessity of using Saudi influence to find indigenous solutions to regional challenges without the need for outside involvement. Improved relations with Saudi Arabia, India thought, would put a lid on Saudi Arabia's readiness to partially support Pakistan's arms acquisitions.

Saudi Foreign Minister Prince Faisal conducted a visit to New Delhi in April 1981. Both countries agreed that the Afghan issue should be resolved, and that "foreign military presence" should be eliminated. The prince informed India's Foreign Minister, Mr. Narasimha Rao, that Saudi Arabia was opposed to foreign military bases being established in the Gulf and in Saudi Arabia. Both believed that the Afghan issue should be resolved through political negotiations Later, during a press briefing, Prince Faisal emphasised that his country does not consider its bilateral relations with any country in the context of its connections with a third country. He acknowledged Saudi Arabia's extensive ties with Pakistan in a variety of spheres, including the military, and stressed that his country wants to strengthen relations with India on their own terms. He disputed the presence of two Pakistani divisions in Saudi Arabia. In April 1982, Mrs. Indira Gandhi, the Indian Prime Minister at the time, paid her maiden visit to Riyadh, the first by an Indian Prime Minister since Nehru's visit in 1956. Indira Gandhi's visit signaled the closing of a "Communication Gap" between the two countries. Mrs. Gandhi's visit to Saudi Arabia ended with a Joint Communiqué expressing broad agreement on a number of subjects.

"The two sides called for a just and comprehensive resolution of the question based on the withdrawal of all foreign forces, strict adherence to non-interference principles, and absolute respect for Afghanistan's freedom, autonomy, territorial integrity, non-aligned status, and membership in the Organization of Islamic Conference," according to the statement. As a result, the fact that little was said about how it could be accomplished indicated that the two sides had simply agreed to disagree on the specifics. Though it was agreed that "the security and stability of the Gulf area is solely the responsibility of the Gulf states, without any foreign interference or intervention," an unstated fact was that few Gulf States were unable to defend themselves without outside assistance. Surprisingly, both sides "acknowledged that the stability and security of the Gulf region and the Indian subcontinent were inextricably linked." This was an implicit admission that, just as India had a legitimate interest in the Gulf, Saudi Arabia had an interest in the Indian subcontinent as 
well. Mrs. Indira Gandhi in her press meet in Riyadh stated that "There should be no foreign intervention, whether military, subversive or otherwise. We have expressed our concerns to the Soviet leaders about the presence of their troops in Afghanistan, both privately and publicly, but we have refrained from condemning them. If they were condemned, one would have to condemn everyone who interfered in other parts of the world in various ways". It should be noted that the visit did not raise the bar to a higher level. the two countries' limited political understanding. This was owing to the fact that broad consensus on topics could not be extended to precise measures required to address any given problem. However, both countries showed maturity and shrewdness in their dealings with one another, allowing them to put little irritants in their ties aside and focus on areas where their broad interests coincided in the long run. According to one publication, Mrs. Gandhi's visit "gave the two countries an opportunity to break out of the constrained relationship they had become stuck into as a result of those old attitudes and suspicions." The visit also resulted in no significant economic agreements, which was a little disappointing. Nonetheless, "it was perhaps appropriate in the context of Mrs. Gandhi's visit that Bilateral economic cooperation should have been given somewhat secondary importance." However, it appears that Mrs. Gandhi's visit to Saudi Arabia did not result in any agreement between these two countries. However, if we look closely, we can see that the visit was not in vain and that it opened up new avenues and opportunities for economic cooperation and other forms of bilateral relations.

Only in the late 1980s did Saudi Arabia's policy toward South Asia begin to shift slowly but noticeably. India's ascent to prominence in West Asia coincided with Saudi Arabia's maturation as a viable Arab state. With the conclusion of the Cold War, the Talibanization of Afghanistan, Indian economic liberalisation, India's development as an information technology giant, and Pakistan's coup, the climate became more conducive for the warming of Indo-Saudi ties. (Dutt, 1999)

\section{Saudi Arabia is enlarging its ties with India.}

One of the reasons for India and Saudi Arabia's increasing connections is their shared worry over terrorism and bloodshed in Afghanistan, as well as Pakistan's role. A high level meeting was deemed necessary by India and Saudi Arabia. Saudi Arabia's attitude toward India changed dramatically in the early 1990s. Religion played no role in Saudi Arabian companies hiring Indian workers; in reality, less than half of them were Muslims. There have been indications that Saudi Arabia's public stance on Kashmir is shifting. Saudi Arabia praised Indian diplomats for their role in calming down Indians in Saudi Arabia during the battle. During the Gulf War, India's Chandra Shekhar government was in active by maintaining close contact with Riyadh. Rajiv Gandhi quickly undid the few steps taken by the Chandra Shekhar government to explore the untapped potentials of Indian foreign policy. Rajiv pressured the government to chop and change its policies to the tune of his own domestic compulsions until the end result was a world far too chaotic for foreign governments to do business with (Aiyer, 1991).

India's substantive relations with Saudi Arabia greatly improved during the 1990s. The number of bilateral visits has a significant impact on Saudi Arabia's opinions of India. Saudi Arabia, for example, took a neutral posture during the Kargil crisis and attempted UN action to resolve the conflict. It advised Pakistan to "resolve its conflict with India by diplomatic means, rather than using force in Kashmir, as this would result in significant human and material losses in both countries. Saudi Arabia's King Fahd called for a peaceful resolution to the India-Pakistan conflict, avoiding any references that could be misinterpreted by New Delhi (Mohan C. R., 1999 July 9). The warmth of Indo-Saudi relations paved the way for more high-level visits, culminating in the visit to Saudi Arabia of External Affairs Minister Jaswant Singh. His bilateral 
talks with Saudi Foreign Minister Prince Al Faisal included a wide range of regional and international issues. The aim of the visit was to strengthen bilateral ties. A Memorandum of Understanding (MoU) on "Foreign Office Consultations" was signed, which will allow for more regular contact between the two domestic establishments (Mohan C., 1999 July 9). Another Memorandum of Understanding $(\mathrm{MoU})$ was signed to tackle violence and drug trafficking; on the bilateral front, the two sides agreed on the importance of revitalising the relationship and decided to reactivate the Joint Commission. It was agreed at the political level that there should be a more frequent exchange of high-level visits.

The terrorist attacks on September 11, 2001, in the United States triggered far-reaching changes in the field that are beyond the scope of this paper. It also had an effect on Indo-Saudi ties. Saudi Foreign Minister Al Faisal told India that 'India's views and position in the current situation were critical.' In these trying times, both parties decided that they needed to stay in touch. Saudi Arabia and India, both of which had endured the horrors of terrorist attacks in their own nations, supported the US strategy of waging war to overthrow dictators. Both sides wrote letters to each other. Saudi Arabia backed the US in its war against terrorism, but not in its military strikes in Afghanistan. India, like the United States, entered the fight against terrorism, but the tensions between India and Pakistan only grew. Pakistan must be restrained by its allies and partners in order to do this. Saudi Arabia has been a long-time ally of Pakistan and seeks regional unity. While Saudi Arabia has moderated its support for Kashmir, it must also limit its financial assistance to Pakistan. The current situation in Afghanistan has also provided India and Saudi Arabia with an opportunity to work together. Now that the Taliban has been deposed and is no longer in force, Pakistan is obligated to work with regional forces on Afghanistan. Saudi Arabia, too, is committed to the restoration of Afghanistan and regional stability. All of this points to the establishment of constructive ties between India and Saudi Arabia. Both, however, are for Afghanistan's restoration and progress, and are providing financial assistance. Saudi Arabia has admitted India as a major regional player and does not want to jeopardise its relations with the nation. India and Saudi Arabia, on the other hand, are exploring new fields of collaboration.

Both India and Saudi Arabia pursued their own foreign policy postures during the US-Iraq war in March 2003, attempting to save their national and international interests. Saudi Arabia did not engage in the war because it did not want to antagonise the US by taking an overt stance on it. Both countries opposed Iraq's dismemberment and advocated for its restoration. After two years, India revealed in November 2005, in a big breakthrough, that Saudi King Abdullah would visit India in early 2006. The Saudi King was the principal guest at the Republic Day festivities in New Delhi on January 26, 2006. He was the first Saudi King to be honoured in this way. Apart from acting as a showcase for the country's military strength as well as secular and democratic principles, the practise of inviting a head of state as the principal guest at the Republic Day Parade every year is now regarded as a barometer of India's regard for that country. In addition, the two nations signed a memorandum of agreement, often known as the Delhi declaration, on concerns like as terrorism and violence. Over 1.5 million Indian employees are working in the kingdom and send lucrative remittances in foreign currency, which account for a significant portion of India's trade bill. The visit of King Abdullah to India has boosted tourist traffic between the two countries significantly.

Saudi Arabia's current "look East" approach began with Saudi support for India after the terrorist attack on the Indian Parliament in 2001, as well as support for the Shimla Deal on Kashmir, rejection of terrorism in India, and a detachment from Pakistan. Saudi Foreign Minister Prince Saud Al Faisal first visited India in February 2006 to follow up on the King's visit, and he came again in February 2008 and December 2008. The Justice Minister, the Minister of Higher 
Education, the Minister of Health, the Minister of Commerce and Industry, and the Minister of Petroleum were among the Saudi ministers who travelled in 2006-08. Prince Muqrin, the Director of Intelligence, paid a two-day visit to India on January 15-16, 2009. Saudi Commerce Minister Abdullah Zainal Alireza paid two visits to India, in August 2009 and November 2010, between the 3rd and 5th of February, 2011. The historic visit of King Abdullah to India in 2006 culminated in the signing of the 'Delhi Declaration, ${ }^{\mathrm{i}}$ giving the bilateral relationship a new lease on life. The visit laid the groundwork for future collaboration in all areas of mutual interest. The reciprocal visit by Prime Minister Dr. Manmohan Singh to Saudi Arabia in 2010 elevated bilateral engagement to 'Strategic Partnership,' and the 'Riyadh Declaration,'ii signed during the visit, encapsulated the spirit of increased collaboration in the political, economic, security, and defence spheres.

Saudi Minister of Economy and Planning Khalid bin Muhammad Al-Qusaibi was in New Delhi for the 'Delhi Sustainable Development Summit.' Sheikh Abdul Rahman Al-Sudais, Grand Imam of Makkah's Holy Mosque, paid a fiveday visit to India in March 2011. Sudais was the first Imam from Makkah to travel to India. On March 28, 2011, as a special envoy of the Saudi King, Prince Bandar bin Sultan, Secretary General of the Saudi National Security Council, visited India and met with Prime Minister Dr. Manmohan Singh. From January 4-6, 2012, Saudi Commerce and Industry Minister Dr. Tawfiq Al-Rabiah led a 76-member delegation to New Delhi for the 9th Indo-Saudi Joint Commission Meeting.

Despite high-level visits from both sides during the Congress Party-led United Progressive Alliance (UPA) years (2004-14), India's passivity in terms of outreach to the major Persian Gulf country continued, despite the country's importance to the region and India's interests there. Since taking office in 2014, Prime Minister Narendra Modi has inherited and revitalised this bilateral warmth, focusing on key areas of mutual interest. In actuality, Modi has revitalised India's relations with the whole Persian Gulf belt by visiting the four main Persian Gulf nations-the United Arab Emirates, Saudi Arabia, Iran, and Qatar-several times since August 2015. A number of high-level discussions took place before Modi's visit to Riyadh in April 2016. Another important sector in which India looks to Gulf countries for FDI in its burgeoning market is investment. Saudi Arabia has shown signs of being a significant source of investments as the Modi administration concentrates on infrastructure and portrays India as a future global industrial powerhouse, thanks to its huge sovereign wealth fund. Saudi businesses spent \$75 million in the Indian market between April 2000 and December 2016. Despite the fact that it was a significant topic of discussion during Modi's April 2016 visit to Riyadh and subsequent meeting with Deputy Crown Prince Muhammad bin Salman in Hangzhou in September, despite the fact that it was lower than other notable investors and its actual potential. In a joint statement released today, India's efforts to improve the ease of doing business in the country, as well as India's important initiatives to simplify and rationalise current policies and reduce foreign direct investment criteria in key industries such as railroads, military, and insurance, were highlighted. India has "encouraged Saudi Aramco, SABIC, and other Saudi businesses to invest in India's infrastructure sector and to engage in projects creating major industrial manufacturing corridors [and] smart cities, as well as the Digital India and Start up India programmes." Saudi Arabia was one of the first countries to denounce the terrorist assault in Uri that killed 18 Indian troops in September 2016, demonstrating the developing strategic arc between Riyadh and New Delhi. Given Saudi Arabia's long-standing pro-Pakistan stance on Kashmir issues, this was a surprising turn of events. In 2017, King Salman concluded a month-long Asian journey focused on strengthening relationships with major Saudi oil importers and promoting a variety of economic prospects. Saudi Arabia's Crown Prince Mohammed Bin Salman (MBS) undertook his own Asia visit two years later in 2019, focusing on Saudi Arabia's strategic and economic partners in the region. On 
September 23, 2020, Saudi Arabia celebrated its 90th national day. The celebrations highlighted developments inside the Kingdom as well as the Kingdom's worldwide position as a key partner of global powers. The Kingdom is undertaking a comprehensive transition, steadily realising the visions of Vision 2030, and has emphasised its economic and strategic relations with Asian Nations in recent years. The bilateral relationship between India and Saudi Arabia is projected to continue to grow. More Saudi investments in India are likely in the immediate term, particularly in infrastructure and development projects, as well as downstream energy projects. India is a key supplier of skilled labor for Saudi Arabia. Saudi Arabia is vital to India since it is a major supplier of oil and remittances.

\section{REFERENCES}

1. Affairs, M. о. (1975). Annual Report (AR), 1974-75, Ministry of External Affairs (MEA). New Delhi, Ministry of External Affairs (MEA.

2. Sana Beg \& Naushadul Haque Mullick, "Increasing Financial Inclusion through Islamic Banking in India ", International Journal of Business Management \& Research (IJBMR),Vol. 6, Issue 1, pp, 27-34

3. Aiyer, S. a. (1991, March 31). India's stand on Gulf leaves its foreign policy in shambles. India Today.

4. Syafruddin Amir, "The Modernization of Education in Islamic Boarding Schools 35 and the Shift of Santri's (Islamic Boarding Student) Politics "International Journal of Educational Science and Research (IJESR), Vol. 9, Issue 2,pp, 33-42

5. Dutt, V. (1999). India's Foreign Policy in a Changing World. New Delhi: Vikas Publishing House.

6. Hussain, I. (1989). Strategic Dimensions of Pakistan's Foreign Policy. Lahore: Progressive Publishers.

7. Rajesh Dahiya \& Saroj Yadav, " Economic Empowerment of Women through Skill Up Gradation ", International Journal of Humanities and Social Sciences (IJHSS), Vol. 7, Issue 3, pp; 13-18

8. Karlovsky, L. (1972). Trade mechanisms in Indus Mesopotamian interrelations. Journal of the American Oriental Society, Vol 92, No 2, 222-229.

9. Mohan, C. R. (1999 July 9). Saudi role in Kargil Endogame. Thiruvananthapuram: The Hindu.

10. Kalim Siddiqui, "Malaysia's Socio-Economic Transformation in Historical Perspective ", International Journal of Business and General Management (IJBGM), Vol.1, Issue 2,pp, 21-50

11. Mohan, C. (1999 July 9). Saudi Role in Kargil Endogame. New Delhi: The Hindu.

12. Mudiam, P. R. ( 1994). India and the Middle East. London: London: British Academic Press.

13. Naaz, F. (2005). West Asia and India Changing Perspectives. Delhi: Shipra Publications.

14. Pasha, A. K. (2006). Indian and Turkey: Past and Emerging Relations. Delhi: Academic Excellence.

15. Pasha, A. K. (2012). New Directions in India's Role in West Asia and the Gulf. Sage Journals, 333-346.

16. Pasha, A. K. (1997). Security and Safety aspects of Haj. India: The Pioneer.

17. Rai, H. A. ( 1981). Pakistan Foreign Policy, Vol. II. Lahore: Aziz Publishers.

18. Ralph Braibanti. ( 1996). Strategic significance of Pakistan's Foreign Policy. Journal of South Asian and Middle Eastern Studies, Vol. 20. No. 1 , p. 5.

19. Rizvi, H. A. ( 1993). Pakistan and the Geo strategic Environment. New York: Palgrave Macmillan.

20. Ziring, S. B. (1990). Pakistan Foreign Policy: An Historical Analysis. Karachi: Oxford University Press. 


\title{
END NOTES
}

\begin{abstract}
${ }^{i}$ The Custodian of the Two Holy Mosques is a man who is in charge of the two holy mosques. During his State visit to India from January 24 to 27, 2006, King Abdullah bin Abdul Aziz Al Saud of Saudi Arabia held historic meetings with the President of the Republic of India, His Excellency Dr. A.P.J. Abdul Kalam, and Prime Minister of the Republic of India, His Excellency Dr. Manmohan Singh. The two sides exchanged perspectives and held in-depth conversations about their shared interests as well as the region's security, stability, peace, and development. Recognizing that this visit ushers in a new era in India-Saudi Arabia ties and is a watershed moment in the development of greater mutual understanding and collaboration, as well as the formation of a mutually beneficial relationship. Reflecting the belief that both nations are establishing a comprehensive strategic vision and are committed to working closely together for the welfare and prosperity of their peoples, as well as for regional and global peace and stability.

ii. His Excellency Dr. Manmohan Singh, Prime Minister of the Republic of India, conducted an official visit to the Kingdom of Saudi Arabia from February 27 to March 1, 2010, at the request of the Custodian of the Two Holy Mosques, King Abdullah bin Abdulaziz Al Saud. The two leaders discussed the status of the historic Delhi Declaration, which was signed on January 27, 2006, and expressed their pleasure with the steady growth of Saudi-India relations since then. They stressed the necessity of full implementation of the Delhi Declaration through ministerial, official, commercial, academic, media, and other levels of exchange of visits. The two leaders resolved to elevate their collaboration to a strategic partnership spanning security, economic, defence, and political domains, in light of the expansion of ties between the two nations and the potential for future growth. The two presidents reaffirmed their shared aim to develop as knowledge-based economies based on breakthroughs in information technology, space research, and other cutting-edge technologies. Etc. This agreement was signed in Riyadh on Sunday, February 28, 2010 (14 Rabea Alawal, 1431H).
\end{abstract}


